\title{
FOOD CONSUMPTION AND NUTRITIONAL INDICES OF OAK TASAR WORM ANTHERAEA PROYLEI (JOLLY) FED ON QUERCUS GLAUCA
}

\author{
${ }^{* 1}$ G. Pathak, ${ }^{1}$ H. Pande Lohani, ${ }^{1}$ J. Siddhu, ${ }^{1}$ B. R. Kaushal and ${ }^{2}$ S. Palliwal \\ ${ }^{1}$ Department of Zoology, Kumaun University, Nainital, India. \\ ${ }^{2}$ Scientist D, Regional Sericultural Research Station (RSRS), Bhimtal \\ (*Corresponding author email: pathakg946@gmail.com) \\ (dr.himanshulohani@gmail.com)
}

\begin{abstract}
Studies were conducted under laboratory conditions to evaluate the food consumption and nutritional indices for the development of Antheraea proylei larvae fed on Quercus glauca. Larval duration was 5.4 \pm 0.489 , $6.4 \pm 0.48,7.2 \pm 0.4,9.8 \pm 0.74$ and $14.2 \pm 0.74$ days in the $1^{\text {st }}, 2^{\text {nd }}, 3^{\text {rd }}, 4^{\text {th }}$ and $5^{\text {th }}$ instars, respectively. Larvae consumed a total of $28.85 \mathrm{~g}$ insect $^{-1}$ day $^{-1}$, egested $4.164 \mathrm{~g}$ insect $^{-1}$ day $^{-1}$ and assimilated $24.69 \mathrm{~g}_{\text {insect }}{ }^{-1}$ day $^{-1}$ of food provided. $82.3 \%$ of tissue growth was observed in the $4^{\text {th }}$ and $5^{\text {th }}$ instar larvae. Approximate digestibility (AD) decreased from $91.94 \%$ in the first instar larva to $80.79 \%$ in the $5^{\text {th }}$ instar larva. Efficiency of conversion of digested food (ECD) into body tissue and efficiency of conversion of ingested food into growth (ECI) increased from $1^{\text {st }}$ instar larva to $5^{\text {th }}$ instar larva. The result obtained in the present study indicate that $Q$. glauca could serve as an alternate host plant for rearing A. proylei in areas where the main host plant $Q$. serrata is not found.
\end{abstract}

KEYWORDS- Antheraea proylei, Consumption, Assimilation, Nutritional indices, Quercus glauca

\section{INTRODUCTION}

Non-mulberry sericulture is universally known as forest and wild sericulture. India is a home for wild sericigenous insects and is the centre of wild silk culture including Eri, Muga and Tasar in both tropical and temperate regions $\mathbf{~}^{\mathbf{1 2}}$. Nearly forty different species of wild silkmoths producing nonmulberry silk have been reported from India ${ }^{1}$. Of these, the most common Indian species reported in the sub Himalayan belt are Antheraea proylei, A. roylei and $A$. pernyi ${ }^{5}$. In India, $A$. proyle $i$ is bivoltine and most common silkmoth used in the production of tasar silk in many states viz. Uttarakhand, Manipur, Himanchal Pradesh, Meghalaya and Jammu and Kashmir.

The quality and quantity of host plants affect the life-history of lepidopteron larvae by affecting the survival rate of different stages, sex ratio and reproduction ${ }^{4,13,15}$. Energy flow studies through different larval stages of lepidopterans have been reported $6,8,1018,19,20,21$

Food consumption and nutritional indices through larval stages of A. proylei fed on Quercus glauca were investigated under laboratory conditions for the first time. The results of this study will provide useful information on production of cocoons by rearing A. proylei on $Q$. glauca as an alternative to the natural host plant $Q$. serrata.

\section{MATERIALS AND METHOD}

For rearing, the eggs of $A$. proylei were 
procured from Regional Sericultural Research Station (RSRS), Bhimtal and kept in petri-dishes for maintaining a stock culture in laboratory. Eggs were reared in a room temperature of $24-25^{\circ} \mathrm{C}$ and a relative humidity of $65-70 \%$. After emerging out, the larvae are provided with the leaves of a host plant i.e. Q. glauca. The larvae because of their soft jaws were firstly fed on soft tendor leaves till its $3^{\text {rd }}$ stage and later instars were fed on mature leaves.

The weight of each larvae was measured in a weighing machine before the start of experiment and then placed on a plant twig kept inside bottle of length 25 $\mathrm{cm}$ and $8 \mathrm{~cm}$ diameter. The larvae were allowed to feed for about $24 \mathrm{hrs}$. The unconsumed leaves and egesta were collected separately from each petridishes and weighed. The larvae were also weighed after feeding for $24 \mathrm{hrs}$.

The unconsumed leaves and egesta were then oven-dried at $65^{\circ} \mathrm{C}$ for $24 \mathrm{hrs}$ and re-weighed till a constant weight was reached. The experiment was repeated for different instars of larvae, but not for the first instar because they are too small and could not be handled easily, and an average value was calculated for each replicate at different stages.

Food consumption was calculated as the difference between the initial weight of leaves provided and the weight of unconsumed leaves.

Assimilation was estimated by subtracting the weight of fecal matter from the weight of food consumed, while increase in body weight was taken as a measure of tissue growth.

Nutritional indices were calculated as follows:

Approximate digestibility (AD) -

$$
\frac{\text { Assimilation }}{\text { Consumption }} \times 100
$$

Tissue growth efficiency (ECD) -

$$
\frac{\text { True growth }}{\text { Assimilation }} \times 100
$$

Ecological growth efficiency (ECI) -

$$
\frac{\text { True growth }}{\text { Consumption }} 100
$$

\section{RESULTS AND DISCUSSION}

The data was recorded for duration of instars, consumption, egesta, assimilation and tissue growth. The data is given in Table 1.

\section{Duration of instars:}

Duration of larval stages was $5.4 \pm 0.489,6.4 \pm 0.48,7.2 \pm 0.4,9.8 \pm 0.74$ and $14.2 \pm 0.74$ days for $1^{\text {st }}, 2^{\text {nd }}, 3^{\text {rd }}, 4^{\text {th }}$ and $5^{\text {th }}$ stages, respectively. Total larval duration was 43.0 days.

\section{Consumption:}

The percentage requirements of food for the consecutive stages calculated from total consumption for the whole developmental period were: $3.4,6.8,14.2$, 22.1 and $53.5 \%$. Total consumption was $28.85 \mathrm{~g} \mathrm{insect}^{-1} \mathrm{day}^{-1}$. A significant correlation was observed between initial 
Table-1. Duration, initial biomass, consumption, egesta, assimilation and tissue growth in Antheraea proylei fed on Quercus glauca

\begin{tabular}{|l|c|c|c|c|c|c|}
\hline $\begin{array}{l}\text { Stage } \\
(\text { Days })\end{array}$ & $\begin{array}{c}\text { Duration } \\
\left(\mathrm{g} \mathrm{insect}^{-1} \text { day }^{-1}\right)\end{array}$ & $\begin{array}{c}\text { Initial Biomass } \\
\left(\mathrm{g} \mathrm{insect}^{-1} \mathrm{day}^{-1}\right)\end{array}$ & $\begin{array}{c}\text { Consumption } \\
\left(\mathrm{g} \mathrm{insect}^{-1} \text { day }^{-1}\right)\end{array}$ & $\begin{array}{c}\text { Egesta } \\
\left(\mathrm{g} \mathrm{insect}^{-1} \text { day }^{-1}\right)\end{array}$ & $\begin{array}{c}\text { Assimilation } \\
\left(\mathrm{g} \mathrm{insect}^{-1} \text { day }^{-1}\right)\end{array}$ & $\begin{array}{c}\text { Tissue Growth } \\
\left(\mathrm{g} \mathrm{insect}^{-1} \text { day }^{-1}\right)\end{array}$ \\
\hline I instar & $5.4 \pm 0.489$ & $0.015 \pm 0.003$ & $0.98 \pm 0.02$ & $0.07 \pm 0.00003$ & $0.90 \pm 0.03$ & $0.0058 \pm 0.001$ \\
\hline II instar & $6.4 \pm 0.48$ & $0.218 \pm 0.004$ & $1.97 \pm 0.095$ & $0.25 \pm 0.021$ & $1.711 \pm 0.071$ & $0.077 \pm 0.004$ \\
\hline III instar & $7.2 \pm 0.4$ & $0.92 \pm 0.033$ & $4.10 \pm 0.07$ & $0.701 \pm 0.04$ & $3.40 \pm 0.12$ & $0.19 \pm 0.01$ \\
\hline IV instar & $9.8 \pm 0.74$ & $2.006 \pm 0.013$ & $6.38 \pm 0.28$ & $1.12 \pm 0.014$ & $5.25 \pm 0.29$ & $0.39 \pm 0.02$ \\
\hline V instar & $14.2 \pm 0.74$ & $5.70 \pm 0.36$ & $15.42 \pm 2.01$ & $2.023 \pm 0.16$ & $13.4 \pm 2.21$ & $0.88 \pm 0.50$ \\
\hline
\end{tabular}

biomass and food consumption (Fig. 1). Egesta:

The steep increase in the amount of food consumed during third, fourth and fifth instars were due to the change in the way the larvae feed and the duration of these instars. The larvae of the first and second instars feed on the bottom of the leaves, eating chiefly the soft palisade tissue and epidermis. In the later instars, the larvae feed upon small veins containing more cellulose, which is a factor deciding the amount of plant mass consumed. The nutritional requirements of insects are associated with biomass and duration of immature stages and has been also reported by Schroeder $^{17}$ and Vats and Kaushal ${ }^{22}$. More than $75 \%$ of the total food was consumed by the last two larval instars because of their higher weight. Similar studies have been reported for other lepidopteran larvae also ${ }^{2,3,11,20}$. Bailey and Singh $^{2}$ reported more than $80 \%$ of the total ingestion in the sixth instar larva of Mamestra configurata.

Higher consumption in the fourth and fifth instar resulted in higher production of egesta by the larvae. These two instars accounted for $75.5 \%$ of the total ingestion. A positive correlation was observed for the food consumed and egestion (Fig. 2).

The quantity of egesta produced by $A$. proylei in the present study is comparable to Waldbaur's ${ }^{23}$ observation on Protoparce sexta and Namin et al. ${ }^{8}$ on Heliothis armigera.

\section{Assimilation:}

A total of $24.661 \mathrm{~g}$ insect $\left\{{ }^{1}\right.$ day ${ }^{1}$ consumed food was assimilated by all the larval instars. The last two assimilated by all the larval instars. The last two instars assimilated $75.7 \%$ of the food consumed. Assimilation increased from $1^{\text {st }}$ instar to the $5^{\text {th }}$ instar larva (Fig. 3). Kaushal and Vats ${ }^{7}$, Namin et al. ${ }^{8}$, Nath et al. ${ }^{10}$ also reported an increase in amount of food assimilated with increased food consumption. 


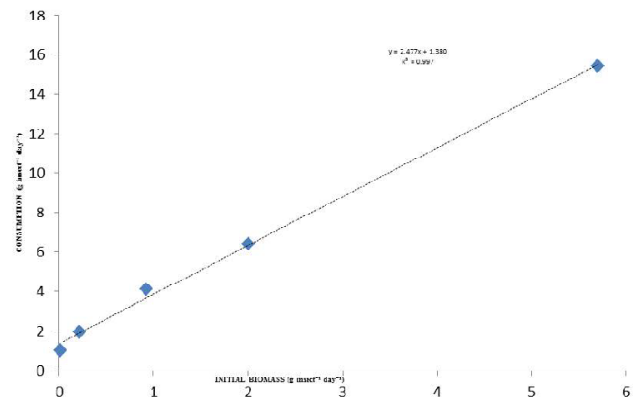

Fig. 1

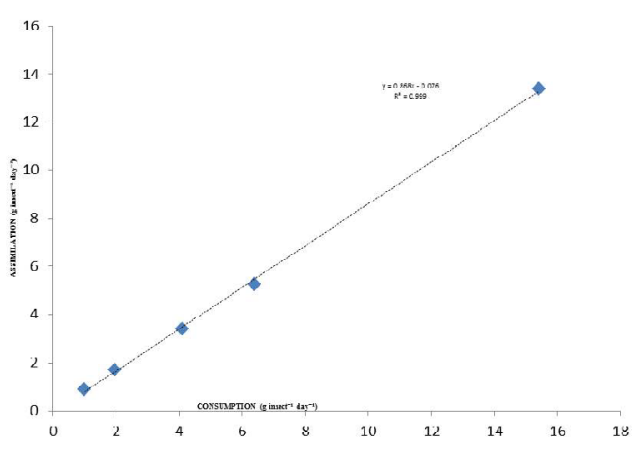

Fig. 3

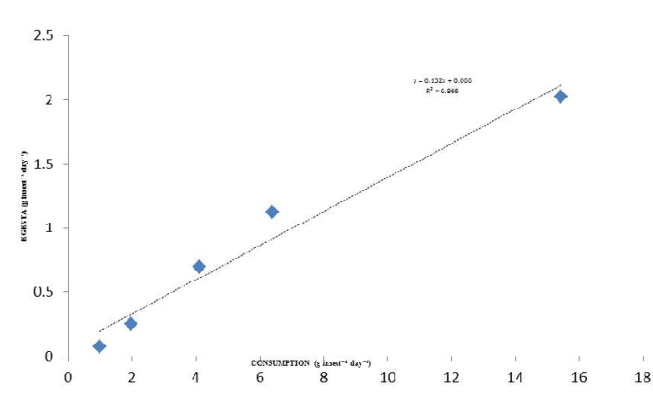

Fig. 2

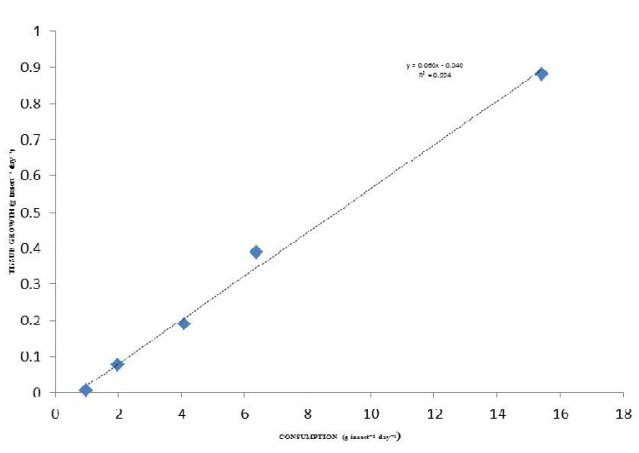

Fig. 4

Fig. 1-4. Nutritional indices of Antheraea proylei fed on Quercus glauca showing relation between:

1. Initial biomass and food consumption

3. Consumption and assimilation

\section{Tissue growth:}

The distribution of tissue growth was $0.37,5.00,12.3,25.3$ and $57.0 \%$ in the $1^{\text {st }}$, $2^{\text {nd }}, 3^{\text {rd }}, 4^{\text {th }}$ and $5^{\text {th }}$ instars, respectively. Fig. 4 represents the relationship between consumption and tissue growth. $90 \%$ to $95 \%$ of the total tissue occurred in the last two instars of Platysomia cercopia ${ }^{\mathbf{1 6}}$, Mamestra configurata $^{2}$ and Helicoverpa armigera similarly, $4^{\text {th }}$ and $5^{\text {th }}$ instars larvae accounted for $82.7 \%$ of the total tissue growth in the present study also. Quality and digestibility
2. Food consumed and egesta

4. Consumption and tissue growth of food has been reported to be responsible for the better growth and larval development ${ }^{8,11,14}$.

\section{Nutritional Indices:}

Percent values of approximate digestibility ( $\mathrm{AD})$, efficiency of conversion of ingested food into tissue growth (ECI) and the efficiency of conversion of digested food into tissue growth (ECD) are presented in Table 2.

Approximate digestibility (AD) was 
maximum in the $1^{\text {st }}$ instar larva $(91.94 \pm 0.56 \%)$ and minimum in the $5^{\text {th }}$ instar larva $(80.79 \pm 11.61 \%)$ in the present study. Waldbaur ${ }^{23}$, Sangha ${ }^{14}$ and Nath et al. ${ }^{10}$ have also reported maximum values of approximate digestibility declined gradually in successive in lepidopteran larvae similar results have also been recorded in the present study.

Table-2. Nutritional indices in Antheraea proylei fed on Quercus glauca (Mean $\pm \mathrm{SE}$ )

\begin{tabular}{|l|c|c|c|}
\hline Stage & $\begin{array}{c}\text { Approximate Digestibility } \\
\text { (AD) }(\boldsymbol{\%})\end{array}$ & $\begin{array}{c}\text { Tissue Growth Efficiency } \\
\text { (ECD) }(\boldsymbol{\%})\end{array}$ & $\begin{array}{c}\text { Ecological Growth Efficiency } \\
\text { (ECI) }(\boldsymbol{\%})\end{array}$ \\
\hline I instar & $91.94 \pm 0.56$ & $0.64 \pm 0.169$ & $0.58 \pm 0.151$ \\
\hline II instar & $86.89 \pm 0.53$ & $4.55 \pm 0.23$ & $3.95 \pm 0.22$ \\
\hline III instar & $82.98 \pm 0.65$ & $5.61 \pm 0.27$ & $4.65 \pm 0.24$ \\
\hline IV instar & $82.10 \pm 0.93$ & $7.43 \pm 0.38$ & $5.98 \pm 0.28$ \\
\hline V instar & $80.79 \pm 11.61$ & $8.80 \pm 1.92$ & $7.63 \pm 1.76$ \\
\hline
\end{tabular}

Efficiency of conversion of ingested food (ECI) is a measure of insects ability to incorporate ingested food into tissue growth, and efficiency of conversion of digested food (ECD) as a parallel parameter, indicates the proportion of digested food converted into net insect biomass (Nathan et al., 2005).

Minimum value of ECI was obtained in the $1^{\text {st }}$ instar larvae $(0.58 \pm 0.15 \%)$ and maximum in the $5^{\text {th }}$ instar larva $(7.63 \pm 1.76 \%)$ in the present study. Similar results have been reported by Nath and Joshi ${ }^{9}$ and Nath et al. ${ }^{\mathbf{1 0}}$ for A. proylei fed on $Q$. leucotrichophora, respectively.

Similarly ECD values also showed an increase from $0.64 \pm 0.17 \%$ in first instar larva to $8.80 \pm 1.92 \%$ in the $5^{\text {th }}$ instar larvae in the present study. These values of ECD are similar to those reported for A. proylei fed on $Q$. leucotrichophora ${ }^{\mathbf{1 0}}$.
The results obtained in the present study indicate that $Q$. glauca could serve as an alternative host plant for rearing of $A$. proylei for production of cocoons in areas where $Q$. serrata trees are not found.

\section{ACKNOWLEDGEMENTS}

The authors express their thanks to the Scientist and other supportive staff of Regional Sericultural Research Station (RSRS), Bhimtal for providing laboratory facilities to carry out the present study.

\section{REFERENCES}

1. Arora, G.S. and I.J. Gupta, 1979. Taxonomic studies of some of the Indian non-mulberry silkmoth (Lepidoptera: Saturniidae). Memoris of Zoological Survey of India., 16: 1-63.

2. Bailey, C.G. and N.B. Singh, 1977. An energy budget for Mamestra configurata (Lepidoptera: Noctuidae). Can. Entomol., 109: 687-693. 
3. Bisht, N.S., K. Bhandari, R. Tripathi and B.R. Kaushal, 2012. Energy budget of Pieris brassicae (Linn.) larvae (Lepidoptera: Pieridae) fed on three host plant species. $J$. Envir. Bio-sci., 26(2): 93-97.

4. Jena, L.K., 2016. Host plant specificity of Indian Tasar Silk insect Antheraea mylitta Dury (Saturniidae) during different seasons. Imp. J.Interdiscip. Res., 2(6): 1414-1420.

5. Jolly, M.S., S.K. Sen, T.N. Sonawalker and G.K. Prasad, 1979. Non-mulberry silks. FAO United Nation. Serv. Bull., 29: 1-178.

6. Joshi, P.C., J.A. Lockwood and N. Vashisth, 2003. Food consumption and assimilation efficiency in Oxya velox (Fabr.) (Orthoptera: Acrididae). Him. J. Env. Zool., 17(1): 39.

7. Kaushal, B.R. and L.K. Vats, 1983. Energy budget of Pieris brassicae L. larvae (Lepidoptera: Pieridae) fed on four host plant species. Agr. Ecosyst. Environ.,10: 385-398.

8. Namin, F.R., B. Naseri and J. Razmjou, 2014. Nutritional performance and activity of some digestive enzymes of cotton bollworm, Helicoverpa armigera in response to seven tested bean cultivars. J. Insect Sci., 14: 1-14.

9. Nath, P. and P.C. Joshi, 2015. Consumption and utilization of food by different instars Oak Tasar worm Antheraea proylei (Jolly) fed on Quercus serrata (Thunb) leaves. N. Y. Sci. J., 8(8): 92-96.

10. Nath, P., P.C. Joshi, S. Kumar, V. Kumar, D.K. Mansotra and M.C. Joshi, 2016. Consumption and utilization of food by different instars of Oak Tasar worm Antheraea proylei (Jolly) fed on Quercus leucotrichophora plant. Int. J. Fauna Biol. Stud., 3(2): 109-112.

11. Naseri, B., Y. Fathipour, S. Moharramipour and V. Hosseninaveh, 2010. Nutritional indices of cotton bollworm, Helicoverpa armigera on 13 Soyabean varieties. J. Insect Sci., 10: $151 *$.

12. Piegler, R.S. and S. Naumann, 2003. Revision of the silkmoth genus Samia. University of the Incarnate word.
13. Ranjan, R.K., A. Muroga and R.K. Datta, 1996. Manual of Young Silkworm Rearing. 14-22.

14. Sangha, K.S., 2011. Feeding performance of Clostera fulgurita in three clones of Populus deltoids. J. Fores. Res., 22(1): 83-86.

15. Scriber, J.M. and F. Slansky, 1981. The nutritional ecology of immature insects. Annu. Rev. Entomol., 26: 183-211.

16. Schroeder, L.A., 1973. Energy budget of the larvae of the moth, Pachysphinx modesta. Oikos., 24: 278-281.

17. Schroeder, L.A., 1976. Energy, matter and nitrogen utilization by the larvae of monarche butterfly, Danaus plexippus. Oikos., 27: 259269.

18. Sharma, P.K. and P.C. Joshi, 2010. Biology of a predatory Coccinellid, Coccinella septumpunctata Linn. (Coleoptera: Coccinellidae). J. Env. Bio-Sci., 24(2): 239.

19. Sinha, U.S.P., C.M. Bajpayee, A.K. Sinha, B.N.B. Chari, and B.R.R.P. Sinha, 2000. Food consumption and utilization in Antheraea mylitta Dury larvae. Intl. J. Wild Silkmoth and Silk., 5: 182-186.

20. Singh, M., H. Pande, J.H. Naik, D. Goswami, and B.R. Kaushal, 2019. Nutritional performance of Pieris brassicae (Lepidoptera: Pieridae) fed on three cruciferous cultivars. Int. J. Res. Anal. Rev., 6(2): 272-278.

21. Sudhansu, S.R., 2010. Food utilization efficiency in Antheraea mylitta fed on Terminalia arjuna leaves. Acad. J. Entomol., 3(1): 23.

22. Vats, L.K and B.R. Kaushal, 1980. Fluctuations of lepidopteran population,secondary productivity and energy flow through Belenois mesentina Cr. (Pieridae). AgroEcosystems., 6: 161-176.

23. Waldbaur, G.P., 1964. Qualitative relationships between number of faecal pellets, faecal weights and weight of food eaten by hornworms, Protoparce sexta (Johan) (Lepidoptera: Sphinidae). Entomol. Exp. Appl., 7: 310-314. 